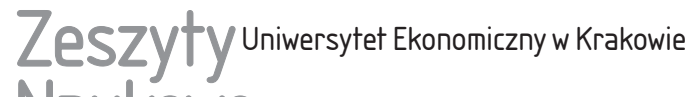 Naukowe
}

$9(957)$

ISSN 1898-6447

Zesz. Nauk. UEK, 2016; 9 (957): 41-54 DOI: 10.15678/ZNUEK.2016.0957.0903

\author{
Jacek Batóg \\ Krzysztof Dmytrów
}

\section{Analiza ścieżek rozwoju gospodarczego polskich regionów}

\section{Streszczenie}

Prezentowane w artykule badanie składa się z dwóch etapów. W pierwszym z nich dokonano analizy porównawczej poziomu rozwoju gospodarczego polskich województw w okresie 2000-2013. W drugim etapie ocenie poddany został stopień podobieństwa rozwoju poszczególnych regionów. W tym celu wykorzystano wybrane miary podobieństwa szeregów czasowych, a zwłaszcza metodę znaną w literaturze pod nazwą dynamic time warping. Punktem wyjścia tej metody jest stworzenie macierzy kosztów, która złożona jest z odległości między wszystkimi parami elementów analizowanych szeregów czasowych. Poszukiwaną miarą podobieństwa jest optymalna ścieżka „przejścia” między punktem początkowym a końcowym, która charakteryzuje się minimalną wartością skumulowanych indywidualnych odległości. Uzyskane wyniki wskazują na wysoki stopień podobieństwa dynamiki oraz na silne zróżnicowanie poziomu rozwoju polskich województw i mogą być wykorzystane w projektowaniu polityki regionalnej, w tym m.in. w określaniu, czy istnieją podstawy do tworzenia wspólnych programów spójności rozwoju dla określonych grup regionów.

Słowa kluczowe: rozwój regionalny, podobieństwo szeregów czasowych, dynamic time warping, kryzys gospodarczy.

Klasyfikacja JEL: C40, O11, O47, R11.

Jacek Batóg, Uniwersytet Szczeciński, Instytut Ekonometrii i Statystyki, Katedra Ekonometrii, 71-101 Szczecin, ul. Mickiewicza 64, e-mail: jacek.batog@usz.edu.pl

Krzysztof Dmytrów, Uniwersytet Szczeciński, Instytut Ekonometrii i Statystyki, Katedra Badań Operacyjnych i Zastosowań Matematyki w Ekonomii, 71-101 Szczecin, ul. Mickiewicza 64, e-mail: krzysztof.dmytrow@usz.edu.pl 


\section{Wprowadzenie}

Umiejętna diagnoza w odniesieniu do gospodarczych, społecznych i terytorialnych aspektów polityki spójności może stać się podstawą prawidłowego określenia nie tylko celów tej polityki, takich jak zmniejszenie dysproporcji w poziomach rozwoju regionów, zwiększania ich konkurencyjności i wzrostu poziomu zatrudnienia, lecz również środków, które doprowadzą do ich osiągnięcia. W zależności od przyjętej koncepcji rozwoju regionalnego w nieco odmienny sposób formułowany jest zbiór decyzji podejmowanych przez polityków i decydentów gospodarczych. Teoretycy i praktycy gospodarczy odwołują się w tym przypadku najczęściej do następujących teorii: teorii neoklasycznej odnoszącej się do migracji siły roboczej i kapitału, teorii wzrostu endogenicznego wykorzystującej ideę potencjału innowacyjnego i otoczenia instytucjonalnego, teorii nowej geografii ekonomicznej opartej głównie na kształtowaniu się kosztów transportu i koncentracji działalności gospodarczej, teorii ewolucyjnej oraz teorii podkreślającej rolę eksportu i wysoko wyspecjalizowanych klastrów.

Bez względu na paradygmat rozwoju regionalnego, który zresztą co pewien czas ulega zmianie, prowadząc politykę w tym obszarze, stajemy często przed problemem oceny stopnia i podobieństwa rozwoju poszczególnych regionów. Jest to potrzebne m.in. przy programowaniu takich działań, jak program operacyjny Rozwój Polski Wschodniej, gdy musimy ustalić, które województwa mogą być włączone do programu oraz w jakich proporcjach należy podzielić między nie ogólną kwotę wsparcia. Kluczową rolę odgrywa w tym przypadku wykorzystanie zmiennej w postaci produktu krajowego brutto per capita, która oprócz tego, że stanowi podstawę podejmowania wielu decyzji nie tylko o charakterze gospodarczym, może być również wykorzystywana w ocenie nierówności dochodowych, w prognozowaniu migracji, dochodów budżetowych i popytu na pracę oraz w planowaniu wydatków na infrastrukturę.

Wiedza o pozycji danego regionu, zwłaszcza w odniesieniu do innych regionów, umożliwia wskazanie obiektu wzorcowego (,[...] dzięki określeniu pozycji obiektu staje się możliwe wskazanie dla każdego obiektu innego obiektu, który go bezpośrednio wyprzedza, taki wyprzedzający obiekt może być modelem rozwoju dla obiektu wyprzedzanego [Hellwig 181, s. 63])" oraz formułowanie ścieżek rozwoju pozwalających osiągnąć modelowy poziom rozwoju (,,[...] znajomość pozycji współrzędnych każdego obiektu umożliwia formułowanie prognoz różnych strategii rozwoju obiektu będącego przedmiotem zainteresowań badawczych, strategie te są formułowane za pomocą metody analogii, która polega na przyjęciu przypuszczeń, iż obiekt obserwowany osiągnie w przyszłości stan podobny do tych, które zostały dziś osiągnięte przez bardziej zaawansowanych rywali" [Hellwig 1981, s. 63]). 
Analiza podobieństwa poszczególnych regionów może też prowadzić do wyodrębnienia klas regionów charakteryzujących się tym samym poziomem (wzorcem) rozwoju.

Podstawowym celem badania jest identyfikacja podobieństwa zmian poziomu rozwoju (mierzonego wartością produktu krajowego per capita) polskich województw w okresie 2000-2013. Szczególny akcent położono w tym przypadku na ocenę wpływu kryzysu gospodarczego, który rozpoczął się w 2007 r., na kształtowanie się tego podobieństwa.

\section{Aktualne trendy w zakresie konwergencji regionalnej w Polsce}

Od wielu lat zarówno w Polsce, jak i w innych krajach Unii Europejskiej obserwujemy zjawisko dywergencji dochodowej w ujęciu regionalnym. Wyniki dotychczasowych badań są zróżnicowane, jednak większość z nich wskazuje na niezadowalające rezultaty dotychczasowej polityki spójności w kontekście likwidacji regionalnych nierówności dochodowych [Batóg 2010, s. 165-167]. Wydaje się, że wzrost zróżnicowania stóp wzrostu gospodarczego oraz poziomu rozwoju poszczególnych regionów jest rezultatem rosnących regionalnych różnic w dostępie do czynników gospodarowania w postaci pracy, kapitału, jak również jakości otoczenia instytucjonalnego. Zjawisko rosnących nierówności dochodowych w Polsce obrazują rys. 1 i 2 . Dla przejrzystości na wykresach nie zamieszczono województwa mazowieckiego, które stanowi obiekt nietypowy i charakteryzuje się znacząco wyższym poziomem PKB per capita w porównaniu do innych województw.

Poziom zróżnicowania dochodowego mierzony współczynnikiem zmienności zwiększył się z 0,21 do 0,25 . Warto jednak zauważyć, że w latach spowolnienia gospodarczego 2002-2003 oraz 2008 obserwowany był chwilowy spadek nierówności dochodowych. PKB per capita najszybciej rósł w województwach dolnośląskim, łódzkim i mazowieckim, dla których średnie tempo zmian tej zmiennej osiągnąło w badanym okresie prawie 7\%. Najniższą dynamiką wzrostu charakteryzowało się województwo zachodniopomorskie ze średnim tempem wzrostu na poziomie $4,86 \%$.

Jednocześnie wyraźnie ukształtował się podział polskich województw na grupę regionów o wysokim i utrzymującym się poziomie rozwoju (mazowieckie, dolnośląskie, wielkopolskie, śląskie i pomorskie), grupę regionów o stałym niskim poziomie rozwoju (podlaskie, lubelskie, podkarpackie, warmińsko-mazurskie i świętokrzyskie) oraz grupę regionów o przeciętnym poziomie rozwoju (łódzkie, małopolskie, zachodniopomorskie, lubuskie, kujawsko-pomorskie i opolskie). 


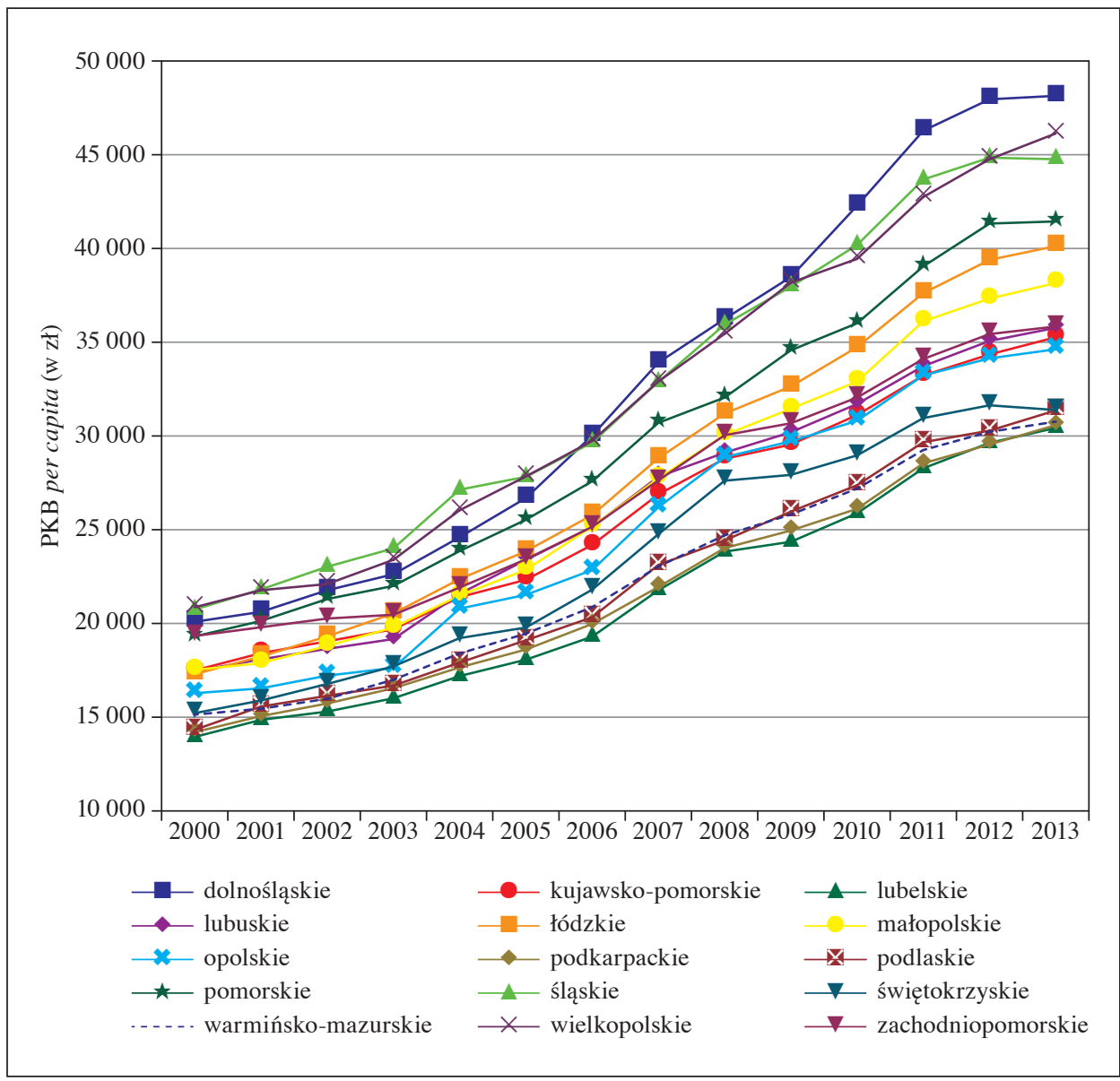

Rys. 1. PKB per capita w polskich województwach w latach 2000-2013 (bez województwa mazowieckiego)

Źródło: obliczenia własne na podstawie Banku Danych Lokalnych, https://bdl.stat.gov.pl/BDL/ dane (dostęp: 12.04.2016).

Obserwowana tendencja, charakteryzująca się dużym stopniem zróżnicowania zmian poziomów rozwoju badanych regionów, utrudnia przewidywanie przyszłych wartości PKB per capita i powoduje, że zamiast prognozowania tej zmiennej dla całej gospodarki należy raczej budować modele prognostyczne dla poszczególnych regionów. Podejście to jest przy tym zgodne z wnioskami z prowadzonych badań, według których podejście bezpośrednie pozwala uwzględnić w procesie prognozowania zróżnicowanie reakcji poszczególnych składników PKB na zachodzące szoki ekonomiczne będące skutkiem specyfiki poszczególnych regionów, co 


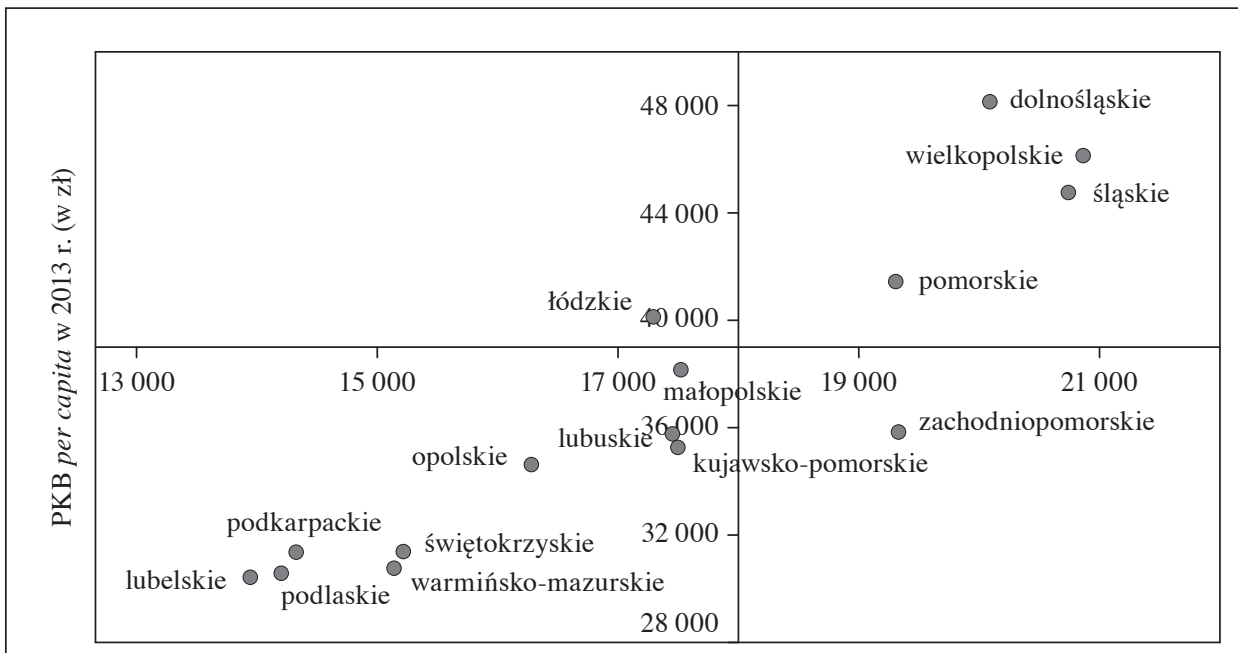

PKB per capita w 2000 r. (w zł)

Rys. 2. Zmiana PKB per capita w polskich województwach w latach 2000-2013 (bez województwa mazowieckiego)

Źródło: obliczenia własne na podstawie Banku Danych Lokalnych, https://bdl.stat.gov.pl/BDL/ dane (dostęp: 12.04.2016).

prowadzi do spadku wariancji predykcji [Zellner i Tobias 2000, Marcellino, Stock i Watson 2003, Demers i Dupuis 2005].

\section{Charakterystyka wykorzystanych miar}

Wyznaczanie scenariuszy rozwoju regionów lub ich ścieżek rozwoju możliwe jest z wykorzystaniem bardzo zróżnicowanych podejść i metod. Dotyczy to również oceny stopnia podobieństwa rozwoju regionów. W celu określenia podobieństwa kształtowania się szeregów czasowych reprezentujących PKB per capita polskich województw w latach 2000-2013 wykorzystano dwie miary. Pierwszą z nich jest miara podobieństwa dwóch funkcji $m$ zaproponowana przez M. Cieślak w pracy [Prognozowanie gospodarcze... 2001, s. 142], natomiast druga miara - dynamic time warping (DTW) - przedstawiona została m.in. w pracach [Sankoff i Kruskal 1999, Berndt i Clifford 1996].

Miara $m$ umożliwia określenie stopnia podobieństwa funkcji $f$ w przedziale $P_{1}$ do funkcji $g$ w przedziale $P_{2}$, a obliczana jest według wzoru:

$$
m=\frac{1}{n} \sum_{i=1}^{n} m_{i},-1<m \leq 1,
$$


gdzie:

$$
m_{i}=\left\{\begin{array}{ccc}
1-\frac{2}{\pi} \alpha_{i} & \text { dla }\left[f\left(a_{i+1}\right)-f\left(a_{i}\right)\right]\left[g\left(c_{i+1}\right)-g\left(c_{i}\right)\right] \geq 0 & 0 \leq \alpha_{i} \leq \frac{\pi}{2} \\
-\frac{\alpha_{i}}{\pi} & \text { dla }\left[f\left(a_{i+1}\right)-f\left(a_{i}\right)\right]\left[g\left(c_{i+1}\right)-g\left(c_{i}\right)\right]<0 & 0<\alpha_{i} \leq \pi
\end{array},\right.
$$

$a_{i}, c_{i}$ - punkty $\mathrm{z}$ - odpowiednio - przedziałów $P_{1}$ oraz $P_{2}$,

$\alpha i$ - miara łukowa kąta zawartego między prostą przechodzącą przez punkty $\left(a_{i}, f\left(a_{i}\right)\right)$ i $\left(a_{i+1}, f\left(a_{i+1}\right)\right)$ a prostą przechodzącą przez punkty $\left(c_{i}, g\left(c_{i}\right)\right)$ i $\left(c_{i+1}\right.$, $\left.g\left(c_{i+1}\right)\right)$.

Nie umożliwia ona jednak wskazania, który „obiekt”, reprezentowany przez dany szereg czasowy, charakteryzuje się bardziej pożądanymi wartościami analizowanego zjawiska. Nie pozwala również obliczyć „odległości” między porównywanymi obiektami.

Miara DTW umożliwia ocenę podobieństwa dwóch szeregów czasowych $X$ i $Y$ poprzez znalezienie optymalnej ścieżki pozwalającej na wyrównanie tych szeregów przy najniższym łącznym koszcie, mierzonym skumulowaną odległością między tymi szeregami, które nie muszą być tej samej długości, co stanowi dużą zaletę tej miary. Wszystkie dopuszczalne ścieżki mają postać:

$$
Z=\left\{z_{1}, z_{2}, \ldots, z_{K}\right\},
$$

gdzie: $z_{k}=\left(n_{k}, m_{k}\right), k=1,2, \ldots, K$, i uzyskiwane są w macierzy kosztów D przy zachowaniu poniższych warunków:

- ograniczoności: pierwszy i ostatni element macierzy kosztów D mają odpowiednio postać:

$$
z_{1}=(1,1) \text { oraz } z_{K}=(N, M),
$$

gdzie $N, M$ oznacza długości - odpowiednio - szeregów czasowych $X$ oraz $Y$,

- monotoniczności i wielkości kroku: ścieżka przesuwa się od początku macierzy kosztów D w kierunku jej prawego górnego rogu, zawsze o jedną komórkę w prawo, do góry lub na ukos.

Aby obliczyć łączną odległość każdej dopuszczalnej ścieżki, tworzona jest macierz skumulowanych kosztów (odległości) $\tilde{\mathrm{D}} \in R^{N \times M}$, przy warunku początkowym $\tilde{d}(1,1)=d(1,1)$ oraz każdym pozostałym elemencie obliczanym według wzoru:

$$
\tilde{d}(n, m)=d(n, m)+\min \{\tilde{d}(n-1, m), \tilde{d}(n, m-1), \tilde{d}(n-1, m-1)\} .
$$

Optymalną ścieżkę, stanowiącą ścieżkę o minimalnym koszcie jednostkowym:

$$
Z^{*}=\left\{z_{1}^{*}, z_{2}^{*}, \ldots, z_{K}^{*}\right\} \text { dla } z_{K}^{*}=(N, M),
$$

wyznaczamy, poruszając się $\mathrm{w}$ macierzy kosztów skumulowanych od punktu $\tilde{d}(N, M)$ w kierunku punktu $\tilde{d}(1,1)$, znając $z_{k}^{*}=(n, m)$ i wybierając jej kolejne elementy na podstawie następującego kryterium: 


$$
z_{k-1}^{*}=\left\{\begin{array}{c}
(1, m-1) \text { dla } n=1 \\
(n-1,1) \text { dla } m=1 \\
\arg \min \{\tilde{d}(n-1, m-1), \tilde{d}(n-1, m), \tilde{d}(n, m-1)\}
\end{array}\right\} .
$$

\section{Uzyskane wyniki}

Zmiany rozwoju polskich województw mierzone z wykorzystaniem miary $m$ charakteryzowały się w całym badanym okresie dużym stopniem podobieństwa (zob. tabela 1). Wysokie wartości miary $m$ oznaczają, że kierunek tych zmian w poszczególnych latach był praktycznie identyczny. Wyjątek stanowiły dwa województwa: śląskie i świętokrzyskie, dla których obserwowany był niższy stopień podobieństwa w odniesieniu do pozostałych regionów.

Znaczący stopień podobieństwa kształtowania się (kierunku zmian) ścieżek rozwoju polskich województw występował również w czasie i bezpośrednio po wybuchu kryzysu gospodarczego (zob. tabela 2).

Dużo większą wartość informacyjną posiada jednak miara DTW. Jej wartości zostały zaprezentowane w tabeli 3 (macierz dla województwa mazowieckiego), w tabeli 4 (macierz dla województwa lubelskiego) oraz w tabeli 5 i na rys. 3 (dla wszystkich województw). W przypadku dwóch macierzy mamy możliwość zobaczenia, jak kształtują się wartości macierzy kosztów skumulowanych oraz optymalne ścieżki dla dwóch województw najbardziej różniących się pod względem dynamiki PKB per capita od wartości charakteryzującej przeciętną wartość dla kraju. Województwo mazowieckie charakteryzowało się najwyższym, a województwo lubelskie najniższym poziomem badanej zmiennej. Widzimy odpowiednio przebiegi optymalnych ścieżek (wartości wytłuszczone) powyżej i poniżej bocznej przekątnej, przy czym wartości skumulowanych kosztów są znacznie wyższe dla województwa mazowieckiego. Porównując wartości miary DTW dla pozostałych województw, możemy zauważyć, że najbardziej podobne do całego kraju w poziomie i w tempie rozwoju były województwa: pomorskie, śląskie, wielkopolskie, łódzkie, małopolskie, dolnośląskie. Najbardziej różniły się od całego kraju województwa: mazowieckie - ze względu na bardzo wysoki poziom PKB per capita - oraz lubelskie, podkarpackie, warmińsko-mazurskie, podlaskie i świętokrzyskie - charakteryzujące się znacząco niższym poziomem rozwoju w stosunku do średniej krajowej oraz pozostałych województw.

W tabeli 5 zaprezentowane zostały dla porównania również wartości odległości euklidesowej obliczone dla poszczególnych województw w stosunku do całego kraju. Widoczna jest wysoka zgodność pozycji zajmowanych przez badane obiekty w przypadku obu miar. Nieznaczne różnice dotyczą zamiany miejsc dwóch par województw: śląskiego i wielkopolskiego oraz małopolskiego i dolnośląskiego. 


\begin{tabular}{|c|c|c|c|c|c|c|c|c|c|c|c|c|c|c|c|c|}
\hline 으 & $\stackrel{0}{\circ}$ & $\hat{\sigma}$ & $\hat{\sigma}$ & $\hat{\sigma}$ & $\hat{\sigma}$ & $\hat{\hat{o}}$ & ః. & O. & ڤ. & $\stackrel{n}{\sigma}$ & ڤ. & $\begin{array}{l}\infty \\
\infty \\
\infty \\
0\end{array}$ & $\begin{array}{l}\infty \\
\infty \\
0 \\
0\end{array}$ & $\hat{\sigma}$ & ڤ. & 8 \\
\hline 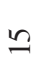 & $\tilde{\sigma}$ & ஃ. & ஃ. & ః. & ó & $\hat{\sigma}$ & $\hat{\sigma}$ & $\begin{array}{l}n \\
\vdots \\
0\end{array}$ & $\hat{\alpha}$ & ڤ. & $\hat{\sigma}$ & $\begin{array}{l}\infty \\
\infty \\
\infty \\
0\end{array}$ & $\begin{array}{l}0 \\
\infty \\
0 \\
0\end{array}$ & $\hat{\alpha}$ & $\underset{-}{8}$ & $x$ \\
\hline$\Xi$ & $\hat{\sigma}$ & $\stackrel{\infty}{\sigma}$ & 亏ू. & ă & हे & $\begin{array}{l}\infty \\
0 \\
0\end{array}$ & $\hat{\sigma}$ & \%. & $\hat{\sigma}$ & \%. & ڤ. & $\begin{array}{l}\hat{\circ} \\
\hat{\theta}\end{array}$ & $\begin{array}{l}\infty \\
\infty \\
0 \\
0\end{array}$ & $\underset{-}{8}$ & $x$ & $x$ \\
\hline$\cong$ & $\begin{array}{c}\infty \\
\infty \\
0\end{array}$ & ळે & 恶 & م. & $\begin{array}{l}\infty \\
\infty \\
0 \\
0\end{array}$ & $\begin{array}{l}\infty \\
\infty \\
0 \\
0\end{array}$ & \&. & $\begin{array}{l}\infty \\
\infty \\
0 \\
0\end{array}$ & $\begin{array}{l}\infty \\
\infty \\
0 \\
0\end{array}$ & $\begin{array}{l}1 \\
\infty \\
0\end{array}$ & $\hat{\infty}$ & $\begin{array}{l}0 \\
0 \\
0\end{array}$ & $\underset{-}{8}$ & $x$ & $x$ & $x$ \\
\hline$\simeq$ & $\begin{array}{l}\infty \\
\infty \\
0 \\
0\end{array}$ & مे & के & $\begin{array}{l}\infty \\
\infty \\
0 \\
0\end{array}$ & ळे & $\begin{array}{l}\hat{\infty} \\
\hat{\theta}\end{array}$ & $\begin{array}{l}\infty \\
\infty \\
0\end{array}$ & 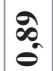 & $\begin{array}{l}2 \\
\hat{\sigma}\end{array}$ & $\begin{array}{l}\infty \\
\infty \\
0 \\
0\end{array}$ & $\begin{array}{l}\infty \\
\infty \\
0 \\
0\end{array}$ & 8 & $x$ & $\times$ & $x$ & $x$ \\
\hline$=$ & $\hat{\sigma}$ & $\stackrel{n}{0}$ & 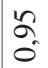 & ڤ. & $\hat{\sigma}$ & $\begin{array}{l}0 \\
0 \\
0\end{array}$ & $\hat{\sigma}$ & Oे. & $\stackrel{n}{\sigma}$ & ڤ. & $\stackrel{8}{\circ}$ & $x$ & $x$ & $x$ & $x$ & $x$ \\
\hline 으 & $\begin{array}{l}\circ \\
\text { م. } \\
0\end{array}$ & â. & ڤ. & ஃ. & ڤ. & $\begin{array}{l}2 \\
0 \\
0\end{array}$ & ă & $\begin{array}{l}n \\
0 \\
0\end{array}$ & $\hat{\sigma}$ & $\stackrel{8}{-}$ & $x$ & $x$ & $\times$ & $x$ & $x$ & $x$ \\
\hline$a$ & ڤ. & $\hat{\sigma}$ & œ人. & ڤ. & ڤ̊. & $\begin{array}{l}\infty \\
2 \\
0\end{array}$ & ڤ. & $\begin{array}{l}n \\
\hat{\sigma}\end{array}$ & 8 & $x$ & $x$ & $x$ & $x$ & $x$ & $x$ & $x$ \\
\hline$\infty$ & $\begin{array}{l} \pm \\
0 \\
0\end{array}$ & ڤ. & 光 & ڤू. & ڤू & $\begin{array}{l}\tilde{\sigma} \\
\hat{\sigma}\end{array}$ & ठू. & 8 & $x$ & $x$ & $x$ & $x$ & $x$ & $x$ & $x$ & $x$ \\
\hline$r$ & $\hat{\sigma}$ & ஃ. & ڤ. & $\hat{a}$ & o. & ڤ. & $\stackrel{8}{\circ}$ & $x$ & $x$ & $x$ & $x$ & $x$ & $x$ & $x$ & $x$ & $x$ \\
\hline 0 & $\hat{\sigma}$ & $\hat{\alpha}$ & $\begin{array}{l}0 \\
0 \\
0\end{array}$ & ஃ. & o̊ & $\underset{-}{8}$ & $x$ & $x$ & $x$ & $x$ & $x$ & $x$ & $x$ & $x$ & $x$ & $x$ \\
\hline in & $\hat{\sigma}$ & $\begin{array}{l}\infty \\
\approx \\
0\end{array}$ & $\hat{\sigma}$ & $\hat{\sigma}$ & $\stackrel{8}{-}$ & $x$ & $x$ & $x$ & $x$ & $x$ & $x$ & $x$ & $x$ & $x$ & $x$ & $x$ \\
\hline t & $\begin{array}{l}\circ \\
\text { ̊. }\end{array}$ & $\hat{a}$ & $\begin{array}{l}0 \\
\circ \\
0\end{array}$ & $\stackrel{8}{\circ}$ & $x$ & $x$ & $x$ & $x$ & $x$ & $x$ & $x$ & $x$ & $x$ & $x$ & $x$ & $x$ \\
\hline$m$ & $\tilde{\sigma}$ & $\stackrel{\infty}{\sigma}$ & $\underset{-}{8}$ & $x$ & $x$ & $x$ & $x$ & $x$ & $x$ & $x$ & $x$ & $x$ & $x$ & $x$ & $x$ & $x$ \\
\hline 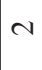 & م. & $\stackrel{8}{-}$ & $x$ & $x$ & $x$ & $x$ & $x$ & $x$ & $x$ & $x$ & $x$ & $x$ & $x$ & $x$ & $x$ & $x$ \\
\hline- & $\stackrel{8}{-}$ & $x$ & $x$ & $x$ & $x$ & $x$ & $x$ & $x$ & $x$ & $x$ & $x$ & $x$ & $x$ & $x$ & $x$ & $x$ \\
\hline $\begin{array}{l}0 \\
3 \\
\frac{1}{N} \\
0 \\
0 \\
0 \\
0 \\
\frac{0}{0} \\
3 \\
3\end{array}$ & 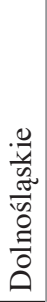 & 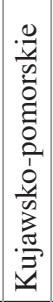 & \begin{tabular}{|l} 
\\
.0 \\
$\frac{0}{0}$ \\
$\frac{0}{0}$ \\
$\frac{0}{3}$ \\
$\frac{0}{3}$
\end{tabular} & 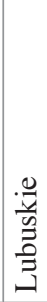 & 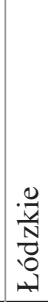 & 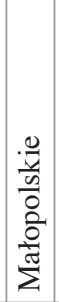 & 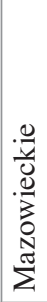 & $\begin{array}{l}\frac{a}{0} \\
\frac{a}{0} \\
0 \\
0 \\
0\end{array}$ & 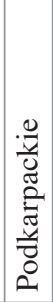 & 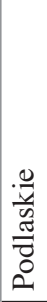 & 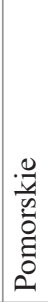 & $\frac{. \frac{\pi}{v}}{\frac{\tilde{E}}{\omega}}$ & 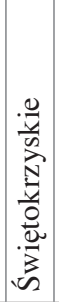 & 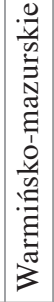 & 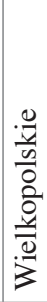 & 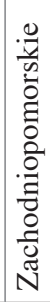 \\
\hline & - & $N$ & $m$ & $\nabla$ & in & 0 & $r$ & $\infty$ & $a$ & 으 & $=$ & $\simeq$ & $\cong$ & \pm & 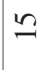 & $\underline{0}$ \\
\hline
\end{tabular}




\begin{tabular}{|c|c|c|c|c|c|c|c|c|c|c|c|c|c|c|c|c|}
\hline 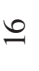 & $\bar{a}$ & $\hat{\sigma}$ & $\hat{\sigma}$ & $\stackrel{0}{\circ}$ & $\hat{a}$ & $\hat{\sigma}$ & S. & Oे. & $\delta$ & $\begin{array}{l}2 \\
0 \\
0\end{array}$ & $\vec{\sigma}$ & $\stackrel{N}{\hat{\sigma}}$ & $\frac{\tilde{r}}{\sigma}$ & $\begin{array}{l}n \\
\hat{\sigma} \\
\end{array}$ & ஓ. & $\stackrel{8}{-}$ \\
\hline$\because$ & $\stackrel{\infty}{\infty}$ & ふू. & $\bar{a}$ & $\hat{\sigma}$ & ふू. & నू & $\hat{\sigma}$ & $\bar{\sigma}$ & ふू & $\delta$ & $\begin{array}{l}\dot{a} \\
0 \\
0\end{array}$ & $\frac{R}{9}$ & $\begin{array}{l}n \\
6 \\
0 \\
0\end{array}$ & $\begin{array}{l}\tilde{\sigma} \\
\sigma\end{array}$ & $\stackrel{8}{\circ}$ & $x$ \\
\hline \pm & $\hat{\sigma}$ & $\frac{n}{\sigma}$ & హ. & $\hat{\sigma}$ & $\stackrel{\infty}{2}$ & ลू. & ڤ. & $\begin{array}{l}0 \\
2 \\
0\end{array}$ & $\frac{n}{2}$ & Oू. & $\bar{\sigma}$ & $\stackrel{n}{\frac{1}{2}}$ & $\underset{\tilde{\sigma}}{\mathbb{N}}$ & 8 & $x$ & $x$ \\
\hline$\cong$ & $\vec{F}$ & $\stackrel{N}{\hat{\sigma}}$ & $\frac{\pi}{6}$ & $\frac{R}{0}$ & $\stackrel{F}{\theta}$ & $\stackrel{\theta}{\pi}$ & ì & $\stackrel{m}{\stackrel{n}{\sigma}}$ & $F_{0}$ & $\begin{array}{l}\infty \\
\vdots \\
0 \\
0\end{array}$ & $\begin{array}{l}\hat{6} \\
0\end{array}$ & ふু & $\stackrel{8}{-}$ & $x$ & $x$ & $x$ \\
\hline$\simeq$ & $\stackrel{b}{\circ}$ & $\stackrel{\mathfrak{N}}{\stackrel{\theta}{\rho}}$ & $\vec{F}$ & $\stackrel{n}{\sigma}$ & $\stackrel{\pi}{\hat{\theta}}$ & $\frac{\pi}{\hat{\theta}}$ & $\frac{\pi}{\sigma}$ & $\frac{\pi}{2}$ & $\frac{m}{\varepsilon}$ & $\frac{1}{2}$ & $\frac{N}{\hat{\theta}}$ & $\stackrel{8}{-}$ & $x$ & $x$ & $x$ & $x$ \\
\hline$=$ & $\bar{\sigma}$ & 占 & 冓 & $\bar{\sigma}$ & گू & ஜू & $\bar{a}$ & 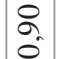 & $\begin{array}{l}\infty \\
\infty \\
0 \\
0\end{array}$ & $\begin{array}{l}\infty \\
\infty \\
0 \\
0\end{array}$ & $\underset{-1}{8}$ & $x$ & $x$ & $x$ & $x$ & $x$ \\
\hline 으 & ஓ. & $\hat{\sigma}$ & $\bar{\sigma}$ & ふू. & $\bar{\sigma}$ & $\hat{\sigma}$ & $\hat{\sigma}$ & $\bar{\sigma}$ & హू. & 8 & $x$ & $x$ & $\times$ & $x$ & $x$ & $x$ \\
\hline$a$ & ఏ. & ڤ. & Oे & बू. & Oे. & $\hat{\sigma}$ & $\bar{\sigma}$ & $\hat{\sigma}$ & $\stackrel{8}{-}$ & $x$ & $x$ & $x$ & $x$ & $x$ & $x$ & $x$ \\
\hline$\infty$ & ๙ু & Oे. & హ. & बू. & $\hat{\sigma}$ & $\begin{array}{l}\infty \\
\sigma \\
0\end{array}$ & Sू & 8 & $x$ & $x$ & $\times$ & $x$ & $\times$ & $x$ & $\times$ & $x$ \\
\hline$r$ & $\hat{\sigma}$ & Oे. & گ̆ & $\tilde{a}$ & $\hat{\sigma}$ & $\hat{\sigma}$ & 8 & $x$ & $x$ & $x$ & $x$ & $x$ & $x$ & $x$ & $\times$ & $x$ \\
\hline 6 & ふू. & ठ̀. & $\hat{\sigma}$ & $\hat{\sigma}$ & $\stackrel{n}{\Omega}$ & $\stackrel{8}{-}$ & $x$ & $x$ & $x$ & $x$ & $x$ & $x$ & $x$ & $x$ & $x$ & $x$ \\
\hline in & Oे. & ڤ̊ & $\stackrel{n}{0}$ & ڤे & 8 & $x$ & $x$ & $x$ & $x$ & $x$ & $\times$ & $x$ & $x$ & $x$ & $x$ & $x$ \\
\hline$\nabla$ & $\hat{\sigma}$ & ஃ̊. & ڤ. & $\stackrel{8}{-}$ & $x$ & $x$ & $x$ & $x$ & $x$ & $x$ & $x$ & $x$ & $x$ & $x$ & $x$ & $x$ \\
\hline$m$ & ळે & oू & $\stackrel{8}{\circ}$ & $x$ & $x$ & $\times$ & $x$ & $x$ & $x$ & $x$ & $x$ & $x$ & $x$ & $x$ & $x$ & $x$ \\
\hline$N$ & $\bar{\sigma}$ & 8 & $x$ & $x$ & $x$ & $\times$ & $x$ & $\times$ & $x$ & $\times$ & $x$ & $x$ & $x$ & $\times$ & $\times$ & $x$ \\
\hline- & $\stackrel{8}{\circ}$ & $x$ & $x$ & $x$ & $x$ & $x$ & $x$ & $x$ & $x$ & $x$ & $x$ & $x$ & $x$ & $x$ & $x$ & $x$ \\
\hline $\begin{array}{l}0 \\
\frac{3}{N} \\
0 \\
0 \\
\frac{0}{0} \\
\frac{0}{2} \\
3\end{array}$ & 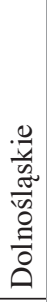 & 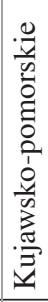 & $\begin{array}{l}\frac{0}{\sqrt[n]{n}} \\
\frac{0}{0} \\
\frac{0}{3} \\
\end{array}$ & 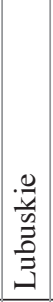 & 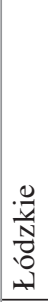 & 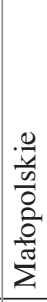 & 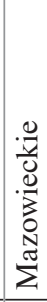 & 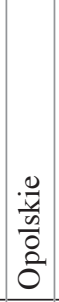 & 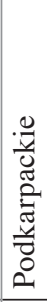 & 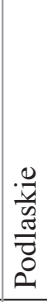 & 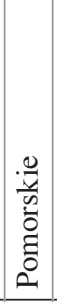 & 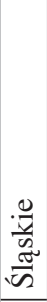 & 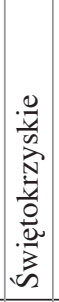 & 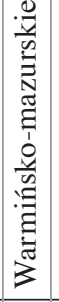 & $\begin{array}{l}\frac{0}{0} \\
\frac{0}{0} \\
0 \\
0 \\
0 \\
0 \\
0 \\
0\end{array}$ & 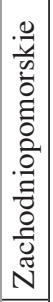 \\
\hline & - & $\sim$ & $m$ & $\nabla$ & $n$ & 0 & $r$ & $\infty$ & $a$ & 으 & $\Xi$ & 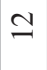 & $\cong$ & \pm & 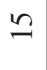 & $\stackrel{0}{0}$ \\
\hline
\end{tabular}




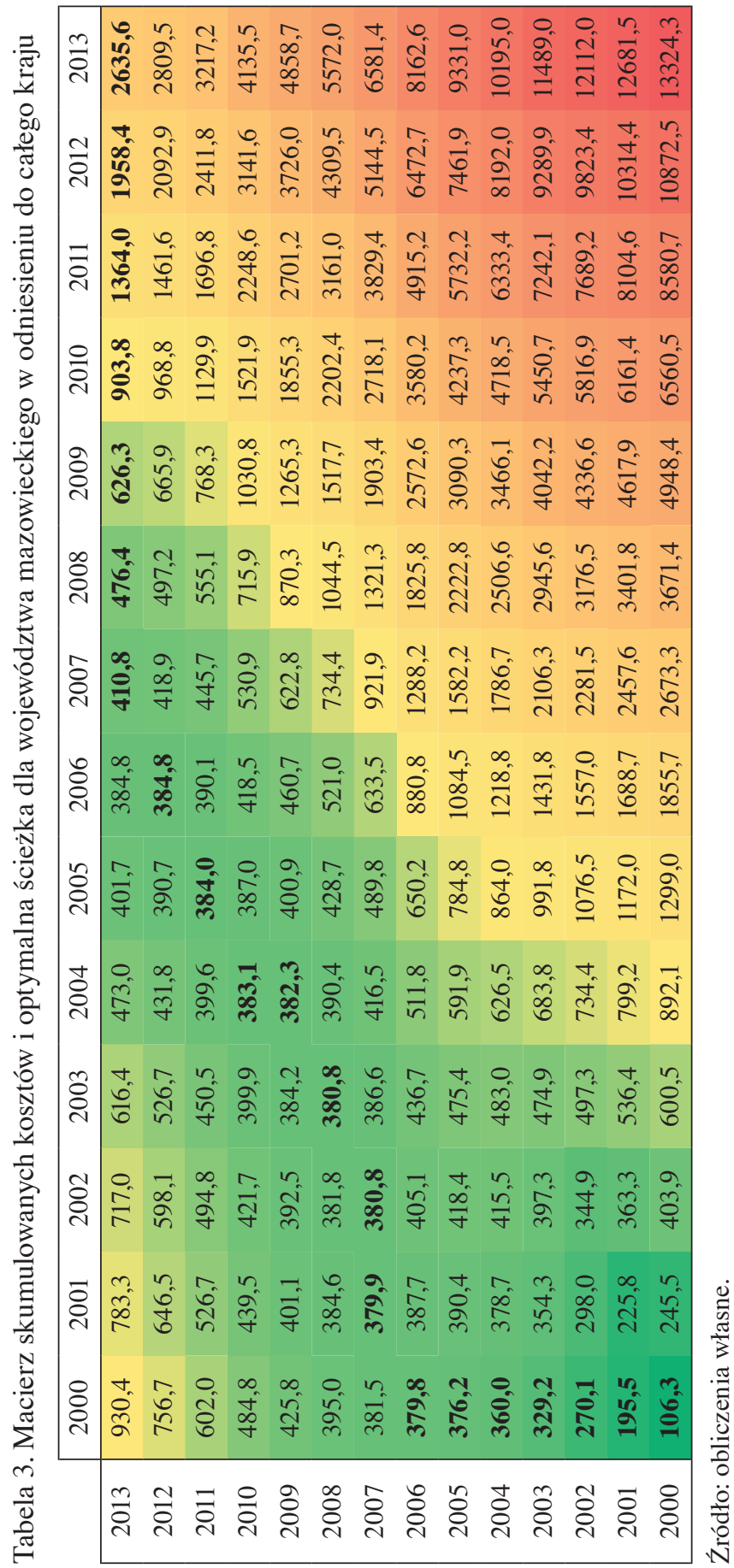




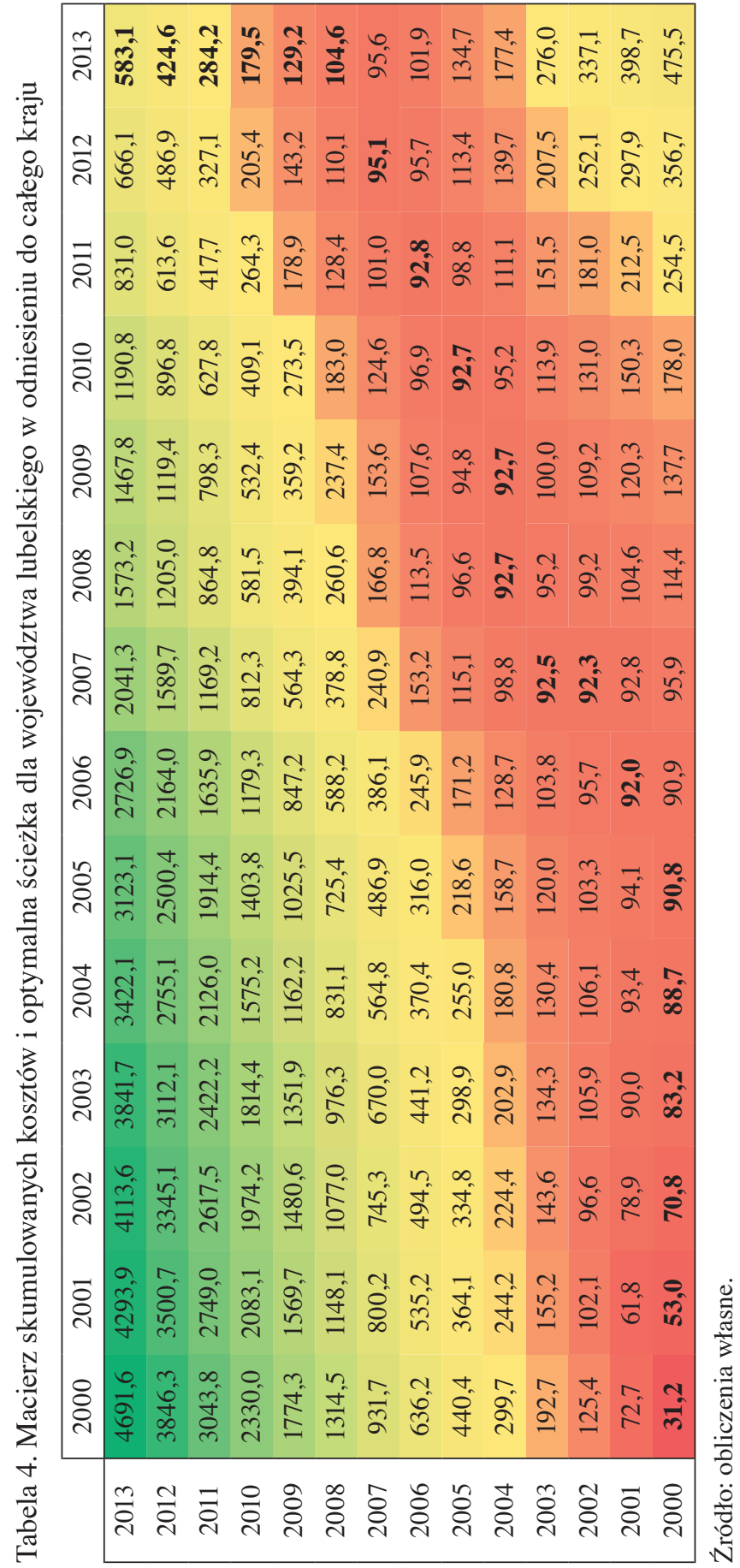


Tabela 5. Podobieństwo zmian poziomu rozwoju województw w odniesieniu do całego kraju w latach 2000-2013 - miara DTW i odległość euklidesowa

\begin{tabular}{|l|c|c|}
\hline \multicolumn{1}{|c|}{ Województwo } & DTW & Odległość euklidesowa \\
\hline Pomorskie & 9,0 & 11,8 \\
\hline Śląskie & $\mathbf{1 6 , 2}$ & $\mathbf{6 6 , 8}$ \\
\hline Wielkopolskie & $\mathbf{2 0 , 3}$ & $\mathbf{5 5 , 1}$ \\
\hline Łódzkie & 24,0 & 80,0 \\
\hline Małopolskie & $\mathbf{5 8 , 5}$ & $\mathbf{1 7 5 , 1}$ \\
\hline Dolnośląskie & $\mathbf{7 0 , 3}$ & $\mathbf{1 4 3 , 6}$ \\
\hline Zachodniopomorskie & 123,7 & 241,0 \\
\hline Lubuskie & 135,0 & 289,8 \\
\hline Kujawsko-pomorskie & 154,8 & 347,1 \\
\hline Opolskie & 209,1 & 433,2 \\
\hline Świętokrzyskie & 428,5 & 725,0 \\
\hline Podlaskie & 470,2 & 988,4 \\
\hline Warmińsko-mazurskie & 515,7 & 989,7 \\
\hline Podkarpackie & 553,6 & 1154,6 \\
\hline Lubelskie & 583,1 & 1229,9 \\
\hline Mazowieckie & 2635,6 & 4410,2 \\
\hline
\end{tabular}

Źródło: obliczenia własne.

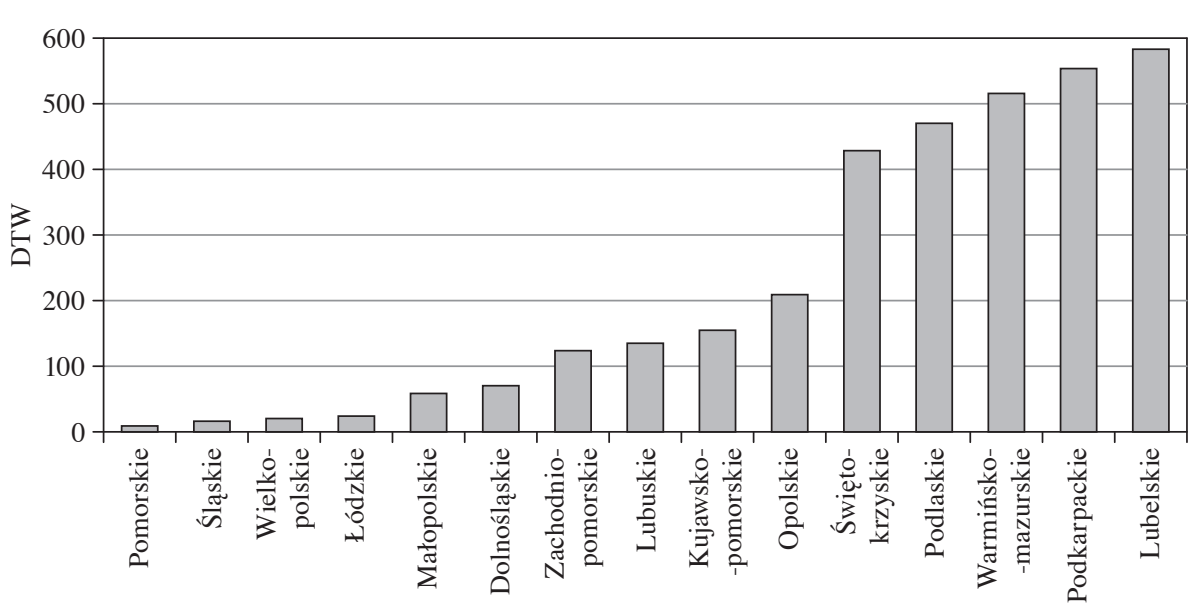

Rys. 3. Wartości miary DTW dla województw w latach 2000-2013 (bez województwa mazowieckiego)

Źródło: obliczenia własne. 
Analizując wartości miary DTW, można np. ocenić podobieństwo przebiegu rozwoju województw dolnośląskiego, lubuskiego, opolskiego, wielkopolskiego i zachodniopomorskiego objętych przyjętą w 2014 r. przez Radę Ministrów strategią rozwoju Polski Zachodniej do roku 2020. Najwyższym stopniem podobieństwa rozwoju charakteryzują się województwa dolnośląskie, zachodniopomorskie i lubuskie, aczkolwiek również dwa pozostałe województwa nie odbiegają od nich znacząco pod względem DTW. Pozwala to, uwzględniając również integrację przestrzenną, przyjąć wniosek o zasadności formułowania strategii łącznego rozwoju tego makroregionu.

\section{Wnioski}

Przeprowadzone badanie pozwala stwierdzić, że dynamikę rozwoju polskich województw w latach 2000-2013 charakteryzował wysoki stopień podobieństwa. Województwa te jednocześnie odznaczały się dużymi różnicami co do poziomu PKB per capita. Wnioskowanie o podobieństwie ścieżek rozwoju gospodarczego za pomocą miary dynamic time warping utrudnia brak unormowania jej wartości. Wydaje się, że w dalszych badaniach można przy użyciu tej miary dokonać porównań regionalnych zmian PKB per capita w ujęciu międzynarodowym. Pozwoliłoby to na ocenę skutków kryzysu gospodarczego ze względu na oczekiwane większe różnice w obserwowanych cyklach koniunkturalnych. Miara DTW może też być wykorzystana w analizie zjawiska konwergencji dochodowej.

\section{Literatura}

Batóg J. [2010], Konwergencja dochodowa w krajach Unii Europejskiej. Analiza ekonometryczna, Rozprawy i Studia, t. 780, Wydawnictwo Naukowe Uniwersytetu Szczecińskiego, Szczecin.

Berndt D.J., Clifford J. [1996], Finding Patterns in Time Series: A Dynamic Programming Approach [w:] Advances in Knowledge Discovery and Data Mining, red. U.M. Fayyad, G. Piatetsky-Shapiro, P. Smyth, R. Uthurusamy, AAAI Press, MIT Press, Menlo Park. Demers F., Dupuis D. [2005], Forecasting Canadian GDP: Region-specific versus Countrywide Information, Bank of Canada Working Paper No. 2005-31, Bank of Canada, Ottawa.

Hellwig Z. [1981], Wielowymiarowa analiza porównawcza i jej zastosowanie w badaniach wielocechowych obiektów gospodarczych [w:] Metody i modele ekonomiczno-matematyczne $w$ doskonaleniu zarzqdzania gospodarkq socjalistycznq, red. W. Welfe, PWE, Warszawa.

Marcellino M., Stock J.H., Watson M.W. [2003], Macroeconomic Forecasting in the Euro Area: Country Specific versus Area-wide Information, „European Economic Review”, vol. 47, nr 1, https://doi.org/10.1016/s0014-2921(02)00206-4. 
Prognozowanie gospodarcze. Metody i zastosowanie [2001], red. M. Cieślak, Wydawnictwo Naukowe PWN, Warszawa.

Sankoff D., Kruskal J. [1999], Time Warps, String Edits, and Macromolecules. The Theory and Practice of Sequence Comparison, CSLI Publications, Stanford.

Zellner A., Tobias J. [2000], A Note on Aggregation, Disaggregation and Forecasting Performance, ,Journal of Forecasting”, vol. 19, nr 5, https://doi.org/10.1002/1099131x(200009)19:5<457::aid-for761>3.3.co;2-y.

\section{An Analysis of Paths of Economic Development of Poland's Regions}

(Abstract)

The research consists of two stages. The first provides a comparative analysis of the level of economic development of Polish voivodships for the period 2000-2013. The second evaluates how similar the paths of economic development of individual regions are. To achieve the latter end, measures of the similarity of time series were applied, particularly dynamic time warping. The starting point for this method is to compute a matrix of costs containing the distances between all the elements of the time series to be analysed (pairwise). The optimum path between the starting and the final points may then be found. This path is characterised by the minimum value of the cumulated distances. The results evidence strong similarities in dynamics and high differences in the level of economic development of Polish voivodships and can be useful for the programming of regional policy, especially for determining whether the foundations for common programmes of the cohesion policy for given groups of regions exist.

Keywords: regional development, similarity of time series, dynamic time warping, economic crisis. 